\title{
Transatlantica
}

Revue d'études américaines. American Studies Journal

Frédérique Spill, The Radiance of Small Things in Ron Rash's Writing

\section{Randall Wilhelm}

\section{(2) OpenEdition}

\section{Journals}

Electronic version

URL: https://journals.openedition.org/transatlantica/16156

DOI: 10.4000/transatlantica. 16156

ISSN: 1765-2766

\section{Publisher}

Association française d'Etudes Américaines (AFEA)

Electronic reference

Randall Wilhelm, "Frédérique Spill, The Radiance of Small Things in Ron Rash's Writing", Transatlantica [Online], 2 | 2020, Online since 01 March 2021, connection on 31 January 2023. URL: http://

journals.openedition.org/transatlantica/16156 ; DOI: https://doi.org/10.4000/transatlantica. 16156

This text was automatically generated on 31 January 2023.

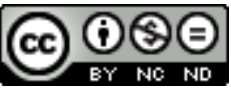

Creative Commons - Attribution-NonCommercial-NoDerivatives 4.0 International - CC BY-NC-ND 4.0

https://creativecommons.org/licenses/by-nc-nd/4.0/ 


\title{
Frédérique Spill, The Radiance of Small Things in Ron Rash's Writing
}

\author{
Randall Wilhelm
}

\section{REFERENCES}

Frédérique Spill, The Radiance of Small Things in Ron Rash's Writing, Columbia: University of South Carolina Press, 2019, 271 pages, hardback, ISBN: 978-1-64336-019-5, \$45.00

1 There is much to admire in Frédérique Spill's recent study The Radiance of Small Things in Ron Rash's Writing. Radiant indeed is a book of scholarship focused exclusively on the writer's use of language, pleasantly unencumbered by the usual phalanx of theoretical conceptualizations. Although informed by the works of Naomi Schor's Reading in Detail, French art historian Daniel Arasse's Take a Closer Look, French philosopher Jean-Claude Milner's La Puissance du détail, and Michael Kowalewski's Deadly Musings: Violence and Verbal Form in American Fiction, Spill's strategy is to zero in "with a sharp eye on small things that somehow contain bigger things, on textual details that may remain unnoticed, but that eventually appear to be fraught with signification" (8). Spill's approach is astutely sensitive and penetrating as she examines Rash's work in a tightly focused deep read that demonstrates the value of New Formalism's call for "a return to the text" in contemporary literary studies. For Spill, the merit of deep reading proves itself on every page, allowing her "to determine how sometimes microscopic objects interact with and eventually reverberate on the totality" of Rash's imaginative world (10). Writing in the distinguished tradition of Francophone formalism shaped by seminal Faulkner scholars such as Andre Bleikasten, Michel Gresset, and François Pitavy, Spill brings to bear an intense scrutiny on Rash's work, a welcome strategy for getting at the heart of Rash's most deeply felt concerns and the craft employed to express them.

2 In her previous monograph, Idiocy in the Works of William Faulkner (L'Idiotie dans l'œuvre de Faulkner, Presses Sorbonne Nouvelle, 2009), Spill had honed her critical practice to 
focus on the structural and affective qualities in language, its melodies and rhythms, its images and aesthetic patterns that generate layered meanings, especially in the notoriously difficult but stunningly electric prose in the Benjy section of The Sound and the Fury. In Radiance, Spill trains her formalist lens on Rash's work, building on previous book-length studies such as John Lang's Understanding Ron Rash (2014), the omnibus The Ron Rash Reader (2014), Mae Claxton's Conversations with Ron Rash (2017), and the collection Summoning the Dead: Essays on Ron Rash (2018). Each of these works provides readers with significant biographical, historical and cultural material as well as critical insight into Rash's work. Spill's monograph, in its format, focus, length and coverage, reigns as the latest jewel in the Rash Studies crown.

Rash's status as an award-winning "triple threat" in poetry, short fiction and the novel presents challenges for any scholar attempting to provide a totalizing vision of his work. The sheer amount of Rash's œuvre-four books of poetry, six short story collections, and six novels from 1994 to 2015-offers another quandary, not only in the wealth of material but also in Rash's tendency to publish in different genres, often alternating between poetry, short story collections and novels. Spill's organization provides one solution to this dilemma. Each of the eleven chapters focuses exclusively on one text, a strategy that allows Spill to reveal figures and patterns in Rash's poetry and prose as well as their recurrence, growth, and transformation from previous and in future works discussed in subsequent chapters. Further unifying her exegesis, Spill argues that Rash's "prose and poetry partake of the same essence" (6); the content from his "spirit world" in the western North Carolina mountains of Appalachia consistently feed and-pardon the pun-"spill" into each other with accumulating energy and power. Regardless of genre, Spill argues-and proves throughout the book-that Rash "draw[s] from the same well of forms and figures, display[s] the same attention to minute particulars, and exhibit[s] the same taut aesthetics" (6) that contribute to his artistic "signature" (188). Such attention to detail and "small things" in Rash's writing allows Spill to shape an encompassing dialogue between his poetry, novels and stories by consistently connecting the intricate details-images, objects, landscapes, atmosphere, seasons, sounds (and many more)-to larger thematic concerns and narrative structures streaming throughout Rash's work that shape the core of his artistic vision.

In her introduction, Spill illuminates perhaps the most singular and evocative small object in the totality of Rash's work, a bead of water on a wet leaf Leonard Shuler sees in his dying moments after plummeting from a cliff in a devastating truck crash in The World Made Straight. Spill calls this image "a quintessential Ron Rash moment-a 'pearl' (5) that encapsulates a character's entire trajectory: "in a single instant, his world appears in a raindrop, evoking how Rash's singular microcosm reflects the vaster world [...] that dramatically exceeds the dimensions of [Leonard's] life and that, he knows, will outlast him and many others" $(5,4)$.

5 Robert Morgan has discussed "the reach of poetry" that can merge the infinitesimal with the cosmic, but in Radiance Spill gives us a deep "reach of criticism" into Rash's world that she describes as "a vast imposing stage" where "minute objects and the subtlest emotions [...] are made to radiate on the larger scenery" (4). Richard Price has called Rash "a gorgeous, brutal writer," and in the image of the raindrop Spill agrees that "it shows how prone Rash is to make death cohabit with beauty, thus imbuing the dreariest situations with a poignant brightness, an unlikely luminescence" (5). 
6 In the first three chapters Spill discusses the range of Rash's poetry, from his first collection Eureka Mill (1998) that focuses on displaced workers in the Piedmont mill system, to his use of more distinctly Appalachian subject matter in the western North Carolina mountains in Among the Believers (2000), to the flooding of the mountain valleys and subsequent loss of land and culture in Raising the Dead (2002). Spill's analysis reflects Rash's stated goal as a poet: "part of the task the poet gives himself is to unearth the underneath, voice the unvoiced, name the unnamed-the unnamable" (44). Spill finds in Rash's poetry a combination of musicality and formal tautness, a forest of sound chimes grooved into the seven-syllable line and patterns of internal rhyme, accentuation, and alliteration inherent to the ancient Welsh form, cynghanedd. Spill's "micro readings" focus on sound and sense, form and content, building on earlier work by Lang and others, including Anthony Hecht, who has called Rash's poetry "a talent of the highest order." When discussing the mechanics of poetic form, Spill makes the material clear and exciting. Rash's poetry is rich in sound, a quality Spill reveals for readers through a series of insightful "close hearings" of important poems that give each collection its distinctively textured world. Through an impressive and sustained focus on rhythm, rhyme and image, Spill reveals the largely unnoticed connective tissues in Rash's poetry while noting important larger differences such as the shift from polyphonic voices and strict adherence to syllabic form in the first two books to a more stabilized voice and a selective loosening of form in Raising the Dead.

If, as Spill argues, sounds inspire poems and visions are harbingers of stories for Rash, the next four chapters are dedicated to how he expands images to the larger canvas of the novel. Part of the pleasure in reading this monograph resides in the continuous surprise at the myriad connections Spill finds, correspondences that lead to larger discoveries and insightful revelations. For instance, in examining the poem "Analepsis" from Among the Believers, Spill reveals a "trembling" theme in the voice of the water that connects to other poems in the volume, and then leaps to a similar aesthetic at work in Rash's first novel, One Foot in Eden (2002), a murder mystery set in the mountain valley of Jocassee before its intentional flooding-a burial by water-for hydroelectric power. Working from small to large, Spill's analysis weaves a pattern of elucidation that continually delights despite the grim subject matter in which Rash often trades. The images that lodge in Rash's mind and refuse to let go until their stories are told range from a farmer with his back turned looking curiously into his field (One Foot in Eden) to a young woman wearing what seemed to be a helmet astride a powerful white horse on a mountain ridge (Serena) to a fish slaughter clogging a creek bed (Above the Waterfall). Spill's focus in these chapters is to trace how small things attach to and deepen the mystery for fundamental concerns: masculinity and gender relations in One Foot in Eden; "antagonist representations" in Saints at the River; violence in The World Made Straight; Shakespearean "traces" in Serena.

8 As the previous chapters make clear, even when writing fiction the elements, tropes, and objects from the poetry-luna moths, white oaks, "play pretties," barbed wire fences, water droplets, speckled trout, black-eyed susans, and many more-appear with regularity in a process typical of Rash's recycling aesthetic. Spill traces an array of quintessential Rashian themes, often in relation to the small things that grow exponentially throughout the novels, especially the complex relations between men and women, the beauty of the Appalachian landscape and its exploitation, violence and resistance, time and fate, choice and circumstance, hope and death. 
9 In Chapter Six on The World Made Straight, for instance, Spill links one of the small objects-an unfired shotgun-to Rash's poetics of violence, which she productively contrasts with similar representations in Flannery O'Connor and William Faulkner, two of Rash's most influential models. While Faulkner silences key moments of violence for a later revelation of intense horror, and O'Connor forces violence upon characters as a way towards grace and salvation, Rash works more circuitously, often showing the marks or stigmata of violence on humans, objects and the land. The weapons owned by his characters are largely semiotic, that is "they hint and somehow counterhint at a sizzling violence, but the violent irruptions will take place elsewhere" (98). Small points about "unnoticed" elements accrue throughout the analysis to build large and powerful insights, allowing readers a wider and deeper understanding of Rash's work with an eye towards his evolving concerns and the strategies used to express them.

In the last four chapters, Spill moves between the genres of poetry (Waking, 2011), novel (The Cove, 2012 and Above the Waterfall, 2015), and short story (Something Rich and Strange, 2014). Although Rash first found national acclaim for his work in poetry, he began as a writer of short stories, publishing The Night the New Jesus Fell to Earth and Other Stories from Cliffside, NC (1994) and Casualties (2000) before focusing on novels. Rash's stories have earned widespread critical praise, with Chemistry and Other Stories (2007) nominated for the Pen/Faulkner Award, and Burning Bright (2010) winning the Frank O'Connor Prize in Short Fiction. By the time Rash had published his sixth novel Above the Waterfall, he had also published six story collections, as well as four volumes of poetry. Spill's greatest dilemma in writing Radiance lodged itself in the breadth and depth of Rash's work in the short story form. Rarely can a scholarly analysis of such extensive material find itself in print, especially today when university presses have slimmed down the standard pagination count. Rather than attempt thin readings that would be a disservice to this work, Spill opts to cover Rash's Something Rich and Strange: New and Selected Stories (2014), a "best of" collection chosen and composed by Rash himself. The decision makes sense, but Spill acknowledges her regret at this restraint.

In the last chapter, Spill takes readers through Rash's most experimental novel, Above the Waterfall, a work that fortuitously unites poetic prose with traditional narrative. Spill's subtitle is "Renewing Wonder," a phrase that resonates with the traumatized character Becky who seeks healing in the Great Smoky Mountains around Cullowhee, North Carolina (the site of Western Carolina University where Rash has worked since 2004). Part of Becky's project is to connect-much like Spill's own strategy throughout Radiance-to a deeper sense of understanding, to merge "world" and "word" and "wonder" in a new language to replace the human sounds in which she has lost faith. As in the previous chapters, Spill shows how the poetic voice that dominates Becky's sections operates through intense scrutiny of the natural world and all its forms. Akin to Benjy Compson's sensory-laden chapter in The Sound and the Fury, Spill demonstrates how Becky's opening section seems like the voice of nature itself as she "watches last light lift off level land" before day and night, earth and sky merge in a coalesced, but temporary, whole. Throughout the chapter Spill continuously reveals the wonder at work in the novel, focusing on the trope of vision as an escape route from what Fredric Jameson has called "the prison house of language." For Spill, "syntactical distortions, hypallage, and synaesthesia associating diverse subtle sensory notations with scattered touches of colors [...] emphasize the painterly qualities of Becky's poetic prose [...] [and] demonstrates the continuity between Rash's poetry and his prose" (175). 
Instead of the usual scholarly conclusion, Spill offers readers three of her previous interviews with Rash in a series of appendices, where Rash can be heard in his own words, an interesting addition that further supports many of Spill's points and forms a solid end frame for her explorations in this monograph. In a conversation regarding the short story, for example, Rash discusses his aesthetics of concision, that he is "often in Poe's camp regarding the 'single effect"' (206) where all details keep readers deep in the story until its inevitable but unforeseen conclusion. While Poe's endings are loaded with ironic twists and shocking revelations, Spill finds that such surprises in Rash's work 'are more likely to be found in small details: the repetition of a word-'map,' 'haversack,' 'mother,' 'lost,'-that gradually acquires the density of a metaphor, a closeup on a hand, or the deceptive vision of a falling star" (206-207). There is clarity in her style, and sentences of spare beauty that reveal Spill's ever-wondrous insights into Rash's literary world. One wishes that such an analysis would never end. But Spill leaves readers with one last "chapter" composed of "a proliferation of endnotes," or "small boxes" which contain even more observations about the multitude of small things peppering Rash's imaginative world. This final section provides "a short, secondary, and [...] independent text" (10) that both fills gaps in the analysis proper and opens spaces for further exploration for a new generation of Rash scholars. In the world of contemporary literary studies that too often places literature at the service of political theory, The Radiance of Small Things shines brightly. Go forth and read.

INDEX

Subjects: Recensions

\section{AUTHORS}

RANDALL WILHELM

Anderson University 